\title{
Protecting a Squaraine near-IR Dye through Its Incorporation in a Slippage-Derived [2]Rotaxane
}

2007

Vol. 9, No. 22

$4523-4526$

\author{
Sheng-Yao Hsueh, ${ }^{\dagger}$ Chien-Chen Lai, ${ }^{\ddagger}$ Yi-Hung Liu, ${ }^{\dagger}$ Yu Wang, ${ }^{\dagger}$ \\ Shie-Ming Peng, ${ }^{\dagger}$ and Sheng-Hsien $\mathrm{Chiu}^{*}, \dagger$
}

Department of Chemistry, National Taiwan University, No. 1, Sec. 4, Roosevelt Road, Taipei, Taiwan 10617, ROC, and Institute of Molecular Biology, National Chung Hsing University and Department of Medical Genetics, China Medical University Hospital, Taichung, Taiwan, ROC

shchiu@ntu.edu.tw

Received August 21, 2007

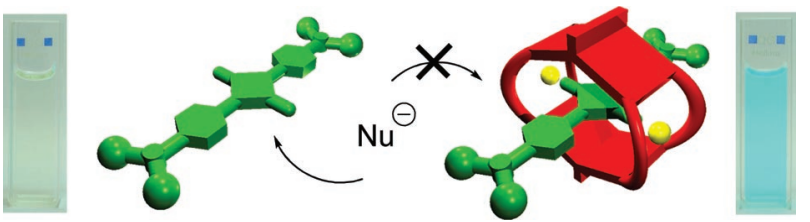

The photophysical properties and chemical stability of a squaraine derivative were enhanced after using $\mathrm{Na}^{+}$ions to template a high-yield slippage synthesis of a [2]rotaxane from the dye and a molecular cage.

Because of their potential use in biomedicine and in materials science, the search continues for new fluorescent near-IR dyes exhibiting narrow absorption, high quantum yield, and enhanced photo- and chemical stability. ${ }^{1}$ Although squaraines are well-established near-IR dyes, their applications are limited by their inherent high electrophilicity, which disrupts their conjugated molecular structures and damages their favorable optical characteristics. ${ }^{2}$ To solve this problem, the concept of encapsulating squaraine dyes has been investigated. ${ }^{3}$ For example, a rotaxane synthesized using the clipping approach ${ }^{4}$ in which a dumbbell-shaped squaraine moiety was used to template the formation of a Leigh-type amide-containing macrocycle-displayed improved chemical

\footnotetext{
$\dagger$ National Taiwan University.

$\doteqdot$ National Chung Hsing University and China Medical University Hospital.

(1) (a) König, K. J. Microsc. 2000, 200, 83. (b) Thomas, K. G.; Kamat, P. V. Acc. Chem. Res. 2003, 36, 888-898.

(2) (a) Ros-Lis, J. V.; Martínez-Máñez, R.; Soto, J. Chem. Commun. 2002, 2248-2249. (b) Ros-Lis, J. V.; García, B.; Jiménez, D.; MartínezMáñez, R.; Sancenón, F.; Soto, J.; Gonzalvo, F.; Valldecabres, M. C. J. Am. Chem. Soc. 2004, 126, 4064-4065.

(3) (a) Das, S.; Thomas, K. G.; George, M. V.; Kamat, P. V. J. Chem. Soc. Faraday Trans. 1992, 88, 3419-3422. (b) Arunkumar, E.; Forbes, C. C.; Smith, B. D. Eur. J. Org. Chem. 2005, 4051-4059.
}

resistance of the squaraine dye. ${ }^{5}$ Unfortunately, this clipping reaction afforded only moderate yields (ca. 28-35\%) of the [2]rotaxane, possibly because of the unavoidable presence of nucleophiles that react with the chemically unstable squaraine-derived dumbbell during the reaction process. Intuitively, use of the slippage approach ${ }^{6}$ toward rotaxane synthesis would minimize the squaraine dye's contact with nucleophiles during the rotaxane formation process. Previously, we reported that $\mathrm{Na}^{+}$ions could be used to template the formation of a [2]pseudorotaxane from a squaraine dye and a molecular cage in $\mathrm{CH}_{3} \mathrm{CN}^{7}$ Herein, we report high-

(4) (a) Jeppesen, J. O.; Perkins, J.; Becher, J.; Stoddart, J. F. Org. Lett. 2000, 2, 3547-3550. (b) Glink, P. T.; Oliva, A. I.; Stoddart, J. F.; White, A. J. P.; Williams, D. J. Angew. Chem., Int. Ed. 2001, 40, 1870-1875. (c) Kay, E. R.; Leigh, D. A. Top. Curr. Chem. 2005, 262, 133-177. (d) Nygaard, S.; Leung, K. C.-F.; Aprahamian, I.; Ikeda, T.; Saha, S.; Laursen, B. W.; Kim, S.-Y.; Hansen, S. W.; Stein, P. C.; Flood, A. H.; Stoddart, J. F.; Jeppesen, J. O. J. Am. Chem. Soc. 2007, 129, 960-970.

(5) (a) Arunkumar, E.; Forbes, C. C.; Noll, B. C.; Smith, B. D. J. Am Chem. Soc. 2005, 127, 3288-3289. (b) Arunkumar, E.; Fu, N.; Smith, B D. Chem. Eur. J. 2006, 12, 4684-4690. (c) Arunkumar, E.; Sudeep, P. K.; Kamat, P. V.; Noll, B. C.; Smith, B. D. New J. Chem. 2007, 31, 677-683. (d) Johnson, J. R.; Fu, N.; Arunkumar, E.; Leevy, W. M.; Gammon, S. T.; Piwnica-Worms, D.; Smith, B. D. Angew. Chem., Int. Ed. 2007, 46, 55285531. 
yield slippage syntheses of corresponding [2] rotaxanes from this unique $\mathrm{Na}^{+}$ion-templated recognition system and the photophysical properties and enhanced chemical stability of the encircled squaraine dye.

Previously, we reported that the molecular cage $\mathbf{1}$ and the threadlike squaraine derivative $\mathbf{2}$ formed pseudorotaxane complexes in the presence of templating $\mathrm{Na}^{+}$ions (Figure $1) .^{7}$ We sought suitable terminal groups for the dumbbell-
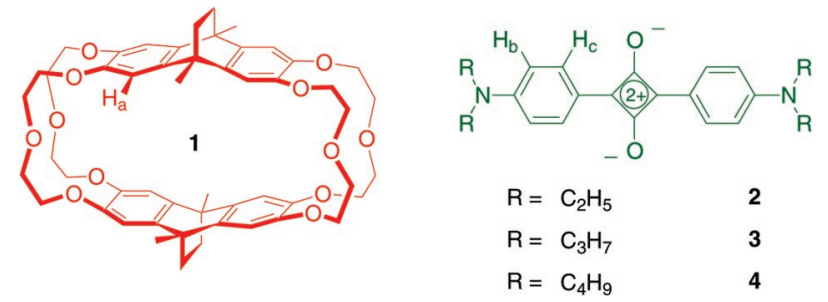

Figure 1.

shaped squaraine in the slippage reaction through a discovery process involving increasing the length of the $\mathrm{N}$-alkyl side chains sequentially, i.e., taking advantage of the gradual increase in the energy barrier for the threading of the squaraine dye through the $\mathrm{Na}^{+}$-ion-complexed molecular cage upon increasing the size and flexibility of the alkyl chains. Thus, we prepared the threadlike squaraine derivatives 3 and $4 .{ }^{8}$ Initially, the ${ }^{1} \mathrm{H}$ NMR spectrum (Figure 2) of a

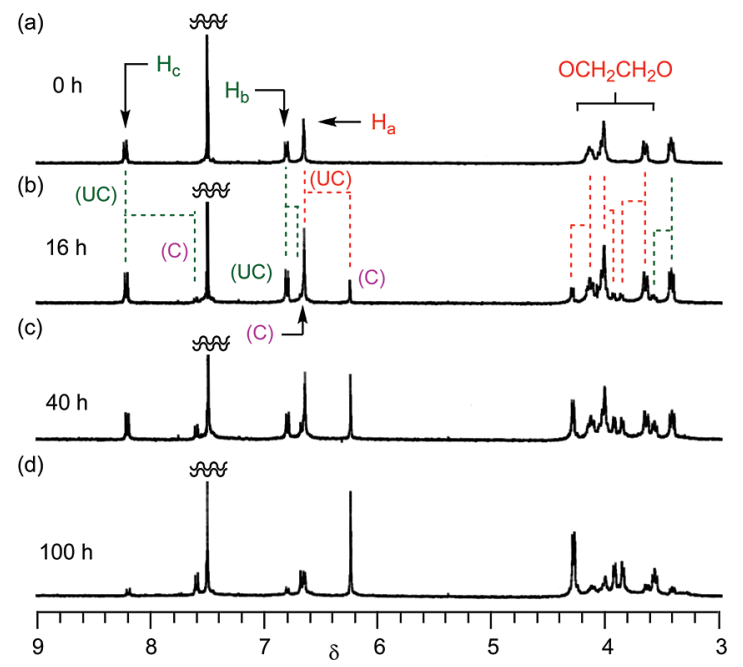

Figure 2. Partial ${ }^{1} \mathrm{H}$ NMR spectra $\left[400 \mathrm{MHz}, \mathrm{CDCl}_{3} / \mathrm{CD}_{3} \mathrm{CN}\right.$ (1:1), $313 \mathrm{~K}$ ] indicating the extent of formation of the [2]rotaxane $\left[\mathbf{3} \subset \mathbf{1} \supset \mathrm{Na}_{2}\right]\left[2 \mathrm{ClO}_{4}\right]$ from a mixture of the molecular cage $\mathbf{1}$, squaraine dye $\mathbf{3}$, and $\mathrm{NaClO}_{4}(2: 2: 4 \mathrm{mM})$ at time intervals of (a) 0 , (b) 16, (c) 40, and (d) $100 \mathrm{~h}$.

mixture of macrocycle $\mathbf{1}$, squaraine $\mathbf{3}$, and $\mathrm{NaClO}_{4}(2: 2: 4$ $\mathrm{mM})$ in $\mathrm{CDCl}_{3} / \mathrm{CD}_{3} \mathrm{CN}$ (1:1) exhibited signals of free $\mathbf{3}$ and the $\mathrm{Na}^{+}$-complexed macrocycle $\mathbf{1}$; we detected a new set of signals after the solution had been heated at $313 \mathrm{~K}$ for $16 \mathrm{~h}$.
The intensity of these new signals increased with time, at the expense of those of free $\mathbf{3}$ and the $\mathrm{Na}^{+}$-complexed macrocycle 1, and became predominant after $100 \mathrm{~h}$. The similar appearance of this new set of signals with respect to those in the ${ }^{1} \mathrm{H}$ NMR spectra ${ }^{7}$ of the pseudorotaxane $\left[2 \subset 1 \supset \mathrm{Na}_{2}\right]\left[2 \mathrm{ClO}_{4}\right]$ suggested that the product was the desired slippage rotaxane $\left[3 \subset \mathbf{1} \supset \mathrm{Na}_{2}\right]\left[2 \mathrm{ClO}_{4}\right]$ (Scheme 1).

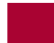

Scheme 1. Using Slippage To Form the [2]Rotaxane $\left[3 \subset 1 \supset \mathrm{Na}_{2}\right]\left[2 \mathrm{ClO}_{4}\right]$

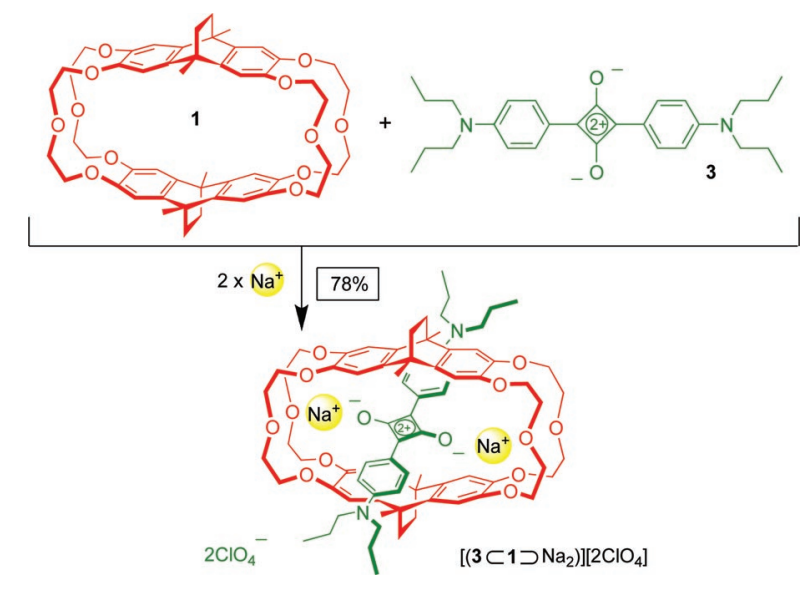

Thus, we repeated this slippage experiment on a larger scale; after allowing the mixture to equilibrate for 7 days, we isolated (column chromatography) the corresponding [2]rotaxane $\left[3 \subset \mathbf{1} \supset \mathrm{Na}_{2}\right]\left[2 \mathrm{ClO}_{4}\right]$ in $78 \%$ yield.

We grew single crystals suitable for X-ray crystallography through liquid diffusion of isopropyl ether into a $\mathrm{CH}_{3} \mathrm{CN}$ solution of the [2]rotaxane $\left[\mathbf{3} \subset \mathbf{1} \supset \mathrm{Na}_{2}\right]\left[2 \mathrm{ClO}_{4}\right] .{ }^{9}$ The solidstate structure (Figure 3) confirms the expected rotaxane molecular geometry of $\left[3 \subset \mathbf{1} \supset \mathrm{Na}_{2}\right]^{2+}$ with the squaraine unit of the dumbbell component located within the molecular cage; the complex was stabilized through interactions of the macrocycle's two [18]crown-6-like units with the two $\mathrm{Na}^{+}$ ions, which were simultaneously bound to the two oxygen atoms of the squaraine unit. ${ }^{10}$

Because the ${ }^{1} \mathrm{H}$ NMR spectrum of a mixture of the macrocycle 1, squaraine $\mathbf{4}$, and $\mathrm{NaClO}_{4}(2: 2: 4 \mathrm{mM})$ in $\mathrm{CDCl}_{3} / \mathrm{CD}_{3} \mathrm{CN}$ (1:1) did not exhibit any signals for a

(6) (a) Asakawa, M.; Ashton, P. R.; Ballardini, R.; Balzani, V.; Belohradsky, M.; Gandolfi, M. T.; Kocian, O.; Prodi, L.; Raymo, F. M.; Stoddart, J. F.; Venturi, M. J. Am. Chem. Soc. 1997, 119, 302-310. (b) Ashton, P. R.; Baxter, I.; Fyfe, M. C. T.; Raymo, F. M.; Spencer, N.; Stoddart, J. F.; White, A. J. P.; Williams, D. J. J. Am. Chem. Soc. 1998, 120, 2297-2307. (c) Chiu, S.-H.; Rowan, S. J.; Cantrill, S. J.; Glink, P. T.; Garrell, R. L.; Stoddart, J. F. Org. Lett. 2000, 2, 3631-3634.

(7) Hsueh, S.-Y.; Lai, C.-C.; Liu, Y.-H.; Peng, S.-M.; Chiu, S.-H. Angew. Chem., Int. Ed. 2007, 46, 2013-2017.

(8) (a) Law, K.-Y.; Bailey, F. C.; Bluett, L. J. Can. J. Chem. 1986, 64, 1607-1619. (b) Law, K.-Y. J. Photochem. A: Chem. 1994, 84, 123-132.

(9) Crystal data for $\left[\left(3 \subset \mathbf{1} \supset \mathrm{Na}_{2}\right) \cdot 4 \mathrm{H}_{2} \mathrm{O}\right]\left[2 \mathrm{ClO}_{4}\right]$ : $\left[\mathrm{C}_{80} \mathrm{H}_{104} \mathrm{O}_{18} \mathrm{~N}_{2} \mathrm{Na}_{2}\right]-$ $\left[\mathrm{ClO}_{4}\right]_{2}, M_{\mathrm{r}}=1626.53$, tetragonal, space group $I 41 / a, a=34.7389(5) \AA$, $b=34.7389(5) \AA, c=14.3489(2) \AA, V=17316.1(4) \AA^{3}, \rho_{\text {calcd }}=1.248$ $\mathrm{g} \mathrm{cm}^{-3}, \mu(\mathrm{Mo} \mathrm{K} \alpha)=0.160 \mathrm{~mm}^{-1}, T=295(2) \mathrm{K}$, orange prisms; 9841 independent measured reflections, $F^{2}$ refinement, $R_{1}=0.0838, w R_{2}=$ 0.2386 . 


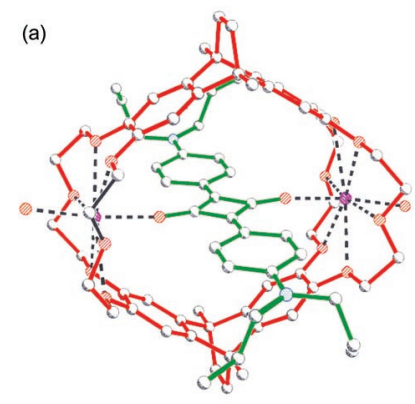

(b)

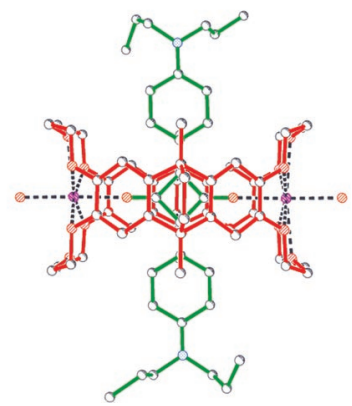

Figure 3. Ball-and-stick representations of the solid-state structure of the [2]rotaxane $\left[\left(3 \subset \mathbf{1} \supset \mathrm{Na}_{2}\right) \cdot 2 \mathrm{H}_{2} \mathrm{O}\right]^{2+}$. Atom labels: C, gray; $\mathrm{O}$, orange; $\mathrm{N}$, blue; $\mathrm{Na}$, pink. Noncoordinated $\mathrm{H}_{2} \mathrm{O}$ molecules and anions have been omitted for clarity.

complex formed between these components, even after heating at $313 \mathrm{~K}$ for $190 \mathrm{~h}$, it appears that $N, N^{\prime}$-di- $n$ butylaniline termini are sufficiently sterically bulky to prevent threading of the squaraine derivative through the cavity of the $\mathrm{Na}^{+}$-complexed molecular cage.

Table 1 lists the photophysical properties of the squaraine derivative $\mathbf{3}$ and the [2]rotaxane $\left[\mathbf{3} \subset \mathbf{1} \supset \mathrm{Na}_{2}\right]\left[2 \mathrm{ClO}_{4}\right]$ in

Table 1. Absorption and Emission Properties of the [2]Rotaxane $\left[\mathbf{3} \subset \mathbf{1} \supset \mathrm{Na}_{2}\right]\left[2 \mathrm{ClO}_{4}\right]$ and Its Free Dumbbell-Shaped Component 3 in $\mathrm{CH}_{3} \mathrm{CN}$

\begin{tabular}{ccccc}
\hline \multicolumn{1}{c}{ compd } & $\lambda_{\mathrm{abs}}$ & $\log \epsilon$ & $\lambda_{\mathrm{em}}{ }^{a}$ & $\Phi_{\mathrm{f}}{ }^{b}$ \\
\hline$\left[\mathbf{3} \subset \mathbf{1} \supset \mathrm{Na}_{2}\right]\left[2 \mathrm{ClO}_{4}\right]$ & 634 & 5.04 & 643 & 0.38 \\
$\mathbf{3}$ & 640 & 5.57 & 656 & 0.13
\end{tabular}

${ }^{a}$ Solutions of $\left[\mathbf{3} \subset \mathbf{1} \supset \mathrm{Na}_{2}\right]\left[2 \mathrm{ClO}_{4}\right]$ and $\mathbf{3}$ were excited at 634 and 640 $\mathrm{nm}$, respectively. ${ }^{b}$ Fluorescence quantum yields were determined using the squaraine dye $\mathbf{4}$ as the standard $\left(\Phi_{\mathrm{f}}=0.15\right.$ in $\mathrm{CH}_{3} \mathrm{CN}$; see ref $\left.8 \mathrm{~b}\right)$; error $\pm 10 \%$.

$\mathrm{CH}_{3} \mathrm{CN}$. Although the absorption and emission maxima of the [2] rotaxane both shifted to slightly shorter wavelengths relative to those of $\mathbf{3}$, the quantum yield increased substantially, presumably because the relatively nonpolar molecular cage partially protected the squaraine dye from solvation by

(10) A molecular cage possessing more sizable [24]crown-8-like units can complex bidentate ligands through the assistance of $\mathrm{K}^{+}$ions; see: Lin, C.-F.; Liu, Y.-H.; Lai, C.-C.; Peng, S.-M.; Chiu, S.-H. Angew. Chem., Int. Ed. 2006, 45, 3176-3181.

Org. Lett., Vol. 9, No. 22, 2007 polar $\mathrm{CH}_{3} \mathrm{CN}$ molecules, reducing the degree of nonradiative relaxation of the squaraine. This hypothesis is supported by our observation that increasing the amount of $\mathrm{CH}_{3} \mathrm{CN}$ in a $1.8 \mu \mathrm{M}$ solution of [2] rotaxane $\left[3 \subset \mathbf{1} \supset \mathrm{Na}_{2}\right]\left[2 \mathrm{ClO}_{4}\right]$ in $\mathrm{CHCl}_{3} /$ $\mathrm{CH}_{3} \mathrm{CN}$ decreased the emission intensity substantially (see the Supporting Information).

Because mercapto groups are good nucleophiles toward squaraine derivatives, ${ }^{2,5}$ we investigated the additional chemical stability imparted upon the squaraine by the encircling molecular cage by treating both the free squaraine derivative $\mathbf{3}$ and its corresponding [2] rotaxane $\left[\mathbf{3} \subset \mathbf{1} \supset \mathrm{Na}_{2}\right]\left[2 \mathrm{ClO}_{4}\right]$ with a large excess of octanethiol in $\mathrm{CH}_{3} \mathrm{CN}$. Figure 4 indicates
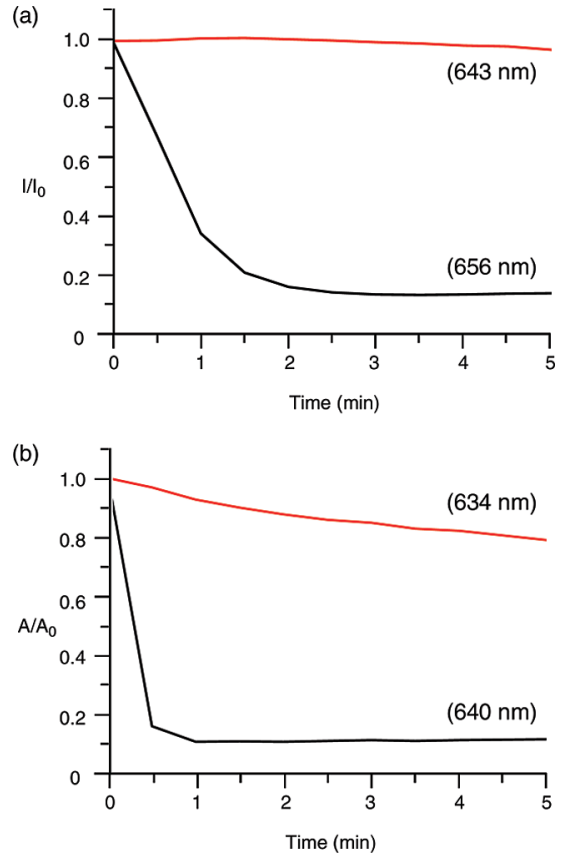

Figure 4. Time profiles of the (a) emission and (b) absorption intensities after the addition of octanethiol $(6 \mathrm{mM})$ to $1.5 \mu \mathrm{M}$ solutions of the threadlike squaraine derivative 3 (black line) and the [2]rotaxane $\left[3 \subset \mathbf{1} \supset \mathrm{Na}_{2}\right]\left[2 \mathrm{ClO}_{4}\right]$ (red line) in $\mathrm{CH}_{3} \mathrm{CN}$ at $298 \mathrm{~K}$.

that when a $1.5 \mu \mathrm{M}$ solution of free 3 in $\mathrm{CH}_{3} \mathrm{CN}$ was mixed with octanethiol $(6 \mathrm{mM})$, both the emission and absorption intensities of the mixture decreased rapidly; in contrast, a mixture of the [2]rotaxane $\left[3 \subset \mathbf{1} \supset \mathrm{Na}_{2}\right]\left[2 \mathrm{ClO}_{4}\right]$ and octanethiol was much more stable under the same conditions: the optical signals retained their high intensities after $5 \mathrm{~min}$. This result suggests that the macrocyclic component of the [2]rotaxane $\left[\mathbf{3} \subset \mathbf{1} \supset \mathrm{Na}_{2}\right]\left[2 \mathrm{ClO}_{4}\right]$ provided a steric shield that protected the squaraine dye from physical interaction with nucleophilic species.

We suspected that the stability of the slippage [2]rotaxane $\left[3 \subset 1 \supset \mathrm{Na}_{2}\right]\left[2 \mathrm{ClO}_{4}\right]$ could be increased through enhancing the complexation of $\mathrm{Na}^{+}$ions to the [18]crown-6-like moieties of the molecular cage; thus, we added various amounts of $\mathrm{NaClO}_{4}$ to a solution of $\left[\mathbf{3 \subset} \supset \mathbf{1} \supset \mathrm{Na}_{2}\right]\left[2 \mathrm{ClO}_{4}\right](1.5$ $\mu \mathrm{M})$ and octanethiol $(6 \mathrm{mM})$. When the concentration of $\mathrm{Na}^{+}$ ions was increased to $7.5 \mu \mathrm{M}$, the corresponding decrease 
in intensity of the absorption band at $634 \mathrm{~nm}$ after $5 \mathrm{~min}$ was less than $2 \%$; i.e., the presence of an excess of $\mathrm{Na}^{+}$ ions stabilized the squaraine dye (Figure 5). ${ }^{11}$ When more

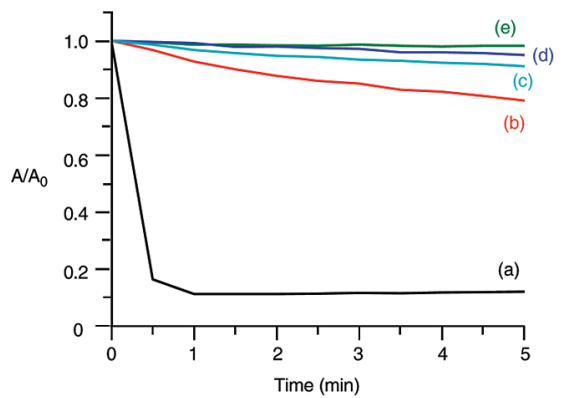

Figure 5. Changes in absorption spectra upon addition of octanethiol $(6 \mathrm{mM})$ to $1.5 \mu \mathrm{M}$ solutions $\left(\mathrm{CH}_{3} \mathrm{CN}, 298 \mathrm{~K}\right)$ of (a) thread $3(640 \mathrm{~nm})$ and $(\mathrm{b}-\mathrm{e})$ [2]rotaxane $\left[3 \subset \mathbf{1} \supset \mathrm{Na}_{2}\right]\left[2 \mathrm{ClO}_{4}\right](634 \mathrm{~nm})$ in the presence of $\mathrm{Na}^{+}$ions at concentrations of (b) 0 , (c) 0.75 , (d) 1.5 , and (e) $7.5 \mu \mathrm{M}$.

polar water molecules were added as a cosolvent to $\mathrm{CH}_{3} \mathrm{CN}$, the interactions between the crown ether moieties and the $\mathrm{Na}^{+}$ions weakened substantially, decreasing the molecular integrity of the [2]rotaxane and, hence, the stability of the squaraine units toward thiol-based nucleophiles. Figure 6 indicates that the [2]rotaxane $\left[\mathbf{3} \subset \mathbf{1} \supset \mathrm{Na}_{2}\right]\left[2 \mathrm{ClO}_{4}\right](0.6 \mu \mathrm{M})$

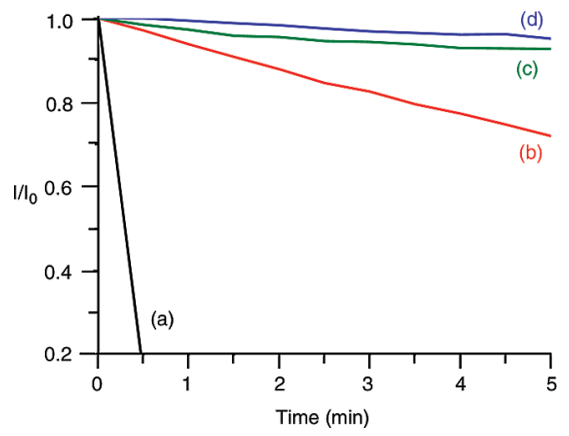

Figure 6. Changes in emission spectra at $643 \mathrm{~nm}$ upon addition of cysteine $(60 \mu \mathrm{M})$ to a solution of the [2]rotaxane $\left[\mathbf{3} \subset \mathbf{1} \supset \mathrm{Na}_{2}\right]$ $\left[2 \mathrm{ClO}_{4}\right](0.6 \mu \mathrm{M})$ in $\mathrm{CH}_{3} \mathrm{CN} / \mathrm{H}_{2} \mathrm{O}(9: 1)$ at $298 \mathrm{~K}$ in the presence of $\mathrm{Na}^{+}$ions at concentrations of (a) 0 , (b) 1.2, (c) 2.4, and (d) $3.0 \mathrm{mM}$.

was destroyed rapidly in a solution of $\mathrm{CH}_{3} \mathrm{CN} / \mathrm{H}_{2} \mathrm{O}$ (9:1) after we had added a large excess of cysteine $(60 \mu \mathrm{M})$. When 1.2 $\mathrm{mM} \mathrm{Na}^{+}$was present in the solution, $30 \%$ of the squaraine dye was destroyed within $5 \mathrm{~min}$, according to the intensity of the emission band at $643 \mathrm{~nm}$; when we increased the concentration of $\mathrm{Na}^{+}$ions to $3 \mathrm{mM}$, the corresponding

(11) According to the intensity of the absorption band at $634 \mathrm{~nm}$, ca. $60 \%$ of the encapsulated squaraine dyes were destroyed after $15 \mathrm{~min}$ in the absence of $\mathrm{Na}^{+}$ions. In the presence of $\mathrm{Na}^{+}$ions $(7.5 \mu \mathrm{M})$, it took $90 \mathrm{~min}$ to destroy the same number of encapsulated squaraine dyes. decrease in intensity of this absorption band was less than $3 \%$ after $5 \mathrm{~min}$, supporting the notion of $\mathrm{Na}^{+}$-assisted stabilization of the squaraine dye under increasingly aqueous conditions.

Figure 7 indicates that, among several physiologically important metal ions, only the presence of $\mathrm{Na}^{+}$ions helped

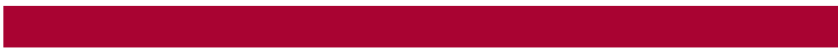

(a)

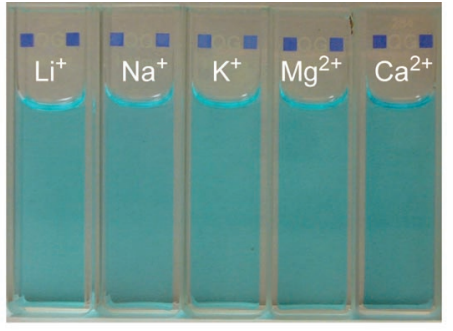

(b)

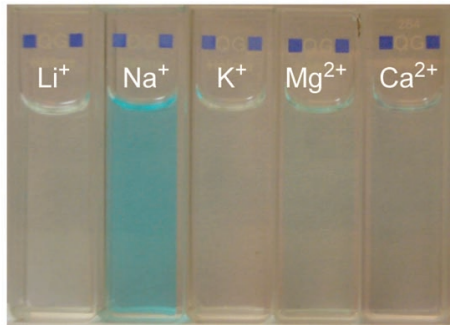

Figure 7. Photographic images of solutions of the [2]rotaxane $\left[3 \subset 1 \supset \mathrm{Na}_{2}\right]\left[2 \mathrm{ClO}_{4}\right](6 \mu \mathrm{M})$ in $\mathrm{CH}_{3} \mathrm{CN} / \mathrm{H}_{2} \mathrm{O}(9: 1)$ containing various physiologically important metal ions $(6 \mathrm{mM})$ in the (a) absence and (b) presence (after $5 \mathrm{~min}$ ) of cysteine $(2.4 \mathrm{mM})$.

to protect the squaraine dye (i.e., maintain its characteristic blue color) from attack by cysteine. This finding supports our previous observation that the formation of the [2]rotaxane was templated by $\mathrm{Na}^{+}$ions in a highly selective manner. ${ }^{7}$ Thus, although the slippage [2]rotaxane $\left[\mathbf{3} \subset \mathbf{1} \supset \mathrm{Na}_{2}\right]\left[2 \mathrm{ClO}_{4}\right]$ is relatively unstable in water, it might be suited to applications in biological systems containing sufficiently high concentrations of $\mathrm{Na}^{+}$ions (e.g., serum).

We have demonstrated that the slippage approach can be used to efficiently encapsulate a squaraine dye in the form of a [2] rotaxane. The encircling molecular cage protected the squaraine moiety from polar solvents-enhancing its quantum yield substantially - and nucleophiles-increasing its stability toward chemical attack. Although the [2]rotaxane was more labile in aqueous solvents, the presence of a high concentration of $\mathrm{Na}^{+}$ions in solution improved its stability; other physiologically important metal ions-namely $\mathrm{Li}^{+}, \mathrm{K}^{+}$, $\mathrm{Mg}^{2+}$, and $\mathrm{Ca}^{2+}$-exhibited no such stabilizing effect.

Acknowledgment. We thank the National Science Council (Taiwan) for financial support (NSC-95-2113-M-002-016MY3).

Supporting Information Available: Synthetic procedures and characterization data for the [2] rotaxane $\left[\mathbf{3} \subset \mathbf{1} \supset \mathrm{Na}_{2}\right]$ $\left[2 \mathrm{ClO}_{4}\right]$. This material is available free of charge via the Internet at http://pubs.acs.org.

OL702050W 